\title{
GOVERNMENT ACTION UNDER CIVIL STATUTE: EFFECT OF PRIOR CRIMINAL ACQUITTAL
}

$\mathrm{T}$ HE DOCTRINE of res judicata precludes identical parties from litigating the same issues in successive civil proceedings. ${ }^{1}$ The Constitution prohibits a second trial of an accused for the same criminal offense. ${ }^{2}$ It is well settled that the outcome of a civil proceeding is not binding upon a party to a later criminal action; ${ }^{3}$ conversely, the outcome of a criminal prosecution is not conclusive upon any issue in a subsequent civil action. ${ }^{4}$ Certain complexities are encountered, however, where the Government has prescribed by statute that some act or omission may give rise to both criminal and civil proceedings. ${ }^{5}$ Under these statutes, it is generally held that a conviction in an earlier criminal action is determinative of the issues therein resolved for the purposes of a later civil action, despite the nature of the second action, because such issues have been previously determined under a more onerous standard of proof. ${ }^{6}$

It is not clear, however, what effect an acquittal in a prior criminal action has upon a subsequent civil proceeding when both actions were

\footnotetext{
${ }^{1}$ See generally, Deolopments in the Law-Res Judicata, 65 HaRv. L. REv. 818 (1952).

U.S. Const. amend. V; Ex parte Lange, 85 U.S. (18 Wall.) 163 (1873). See also Corwin, Constitution of the United States, ANNotated, 837-4I (1952).

${ }^{3}$ The reasons usnally ascribed for this result are that the parties to the actions are not the same, that the amonnt of proof necessary to convict is greater than the amount needed to recover in a civil action and that to allow a civil jndgment to affect a subsequent criminal proceeding would deprive the accused of his constitutional right to confrontation by accusing witnesses. 2 FREEMAN, JUDGMENTs $\S 658$ (5th ed. 1925). United States v. Kwasniewski, 9x F. Supp. 847 (E.D. Mich. 1950); United States v. Konovsky, 202 F.2d 721 (7th Cir. 1953).

'Regardless of the outcome of the criminal prosecution, one who has been damaged by another ordinarily has a claim for redress which is independent of the state's right to proceed against the accused. 2 FREEMAN, JUDGMENTS $\$ 653$ (5th ed. 1925); Chantangco v. Abaroa, 218 U.S. 476 (rgro); Stone v. United States, 167 U.S. 178 (1897).

${ }^{5}$ See, e.g., INT. REV. CODE of 1954, §§ 5174, 5606, 5608, providing that every person having in his control any distilling eqnipment shall'register it and post a bond thereon and that all distilled spirits must be inanufactured in an authorized distillation plant or the manufacturer will be snbject to certain criminal penalties.

Under INT. REv. CODE OF 1954 \&5005(b) every possessor or party inierested in distillery apparatus is liable for a tax upon the spirits produced therefrom.

-Various Items of Personal Property v. United States, 282 U.S. 577 (1931); 2 FreEMAN, JUdGMENTS $\& 657$ (5th ed. 1925).
} 
instituted by the Government. ${ }^{7}$ This question was recently raised in the case of Inman v. United States. ${ }^{8}$ There had been an acquittal in a prosecution alleging violation of criminal statutes pertaining to the illicit distillation of alcoholic spirits. The Commissioner of Internal Revenue subsequently assessed a tax on the defendant in the previous criminal action as being an interested party in certain distilling equipment and mash which had been seized. The District Court, in ordering a refund, concluded that, since the jury in the criminal action had found that the taxpayer had no interest in the illicit spirits or the equipment, this issue, basic in both actions, had been litigated once and for all and could not again be the basis for any punishment. ${ }^{9}$

In upsetting the tax assessment, the court found authority in Coffey v. United States, ${ }^{10}$ where the Supreme Court held that an acquittal in a criminal action was conclusive in a subsequent proceeding in rem involving the same subject matter..$^{11}$ In this case, the Court seemed to suggest two legal bases for the rule, the doctrine of res judicata and the constitutional safeguard against double jeopardy. ${ }^{12}$ Critics have generally argued, however, that neither of these legal principles presents an adequate foundation for the rule. ${ }^{13}$

\footnotetext{
${ }^{7}$ E.g., United States v. 2180 Cases of Champagne, 9 F.2d 710 (2d Cir. 1926); United States v. A Lot of Precious Stones, 134 Fed. 6x (6th Cir. I905); United States v. One De Soto Sedan, 85 F. Supp. 245 (E.D.N.C. x949), holding that a prior acquittal in a criminal action instituted by the government precludes a subsequent civil proceeding. Contra, United States v. One 1953 Oldsmobile, 222 F.2d 668 (4th Cir. 1955); United States v. Gramer, x91 F.2d 74I (gth Cir. x95I); United States v. Physic, x 75 F.2d 338 (2d Cir. x 949); United States v. Certain Bottles of Lee's "Save the Baby," 37 F.2d 137 (D.C. Conn. 1929). The cases are collected in Annot., 27 A.L.R.2d 1132,1142 (1953).

I5I F. Supp. 784 (W.D.S.C. 1957).

Id. at 786.

${ }^{10}$ II 6 U.S. 436 (1886).

${ }^{11}$ The defendant had been acquitted of attempting to defraud the government of revenue by the alteration of revenue stamps which he allegedly intended to place on casks of liquor. The Government then instituted a civil action to seize the liquor.

12 I 16 U.S. at $443-45$.

${ }^{13}$ E.g., McLaren, The Doctrine of Res Judicata As Applied to the Trial of Criminal Cases, 1o WASH. L. REv. 198 (1935); Legis, Note, 5I HARV. L. Rev. Iog2 (1938); Note, 3I Colum. L. Rev. 29I (x93x); 47 HaRv. L. Rev. I438 (1934); 37 MrCH. L. REv. 647 (1938); Note, 25 VA. L. REv. 839 (1939). The dissatisfaction with the Coffey rule has caused the courts to limit severely its application. See United States v. One 1953 Oldsmobile, 222 F.2d 668 (4th Cir. 1955); United States v. Gramer, I9I F.2d 74I (9th Cir. 195 I). The impairment of the efficacy of this rule reached such proportions that one court remarked that "only the shibboleth of stare decisis has saved the Coffey rule from express repudiation." United States v. One Dodge Sedan, II3 F.2d 552, 553 (3d Cir. 1940).
} 
If the Coffey rule is bottomed in the doctrine of res judicata, it may effectively be impaired by the argument that the parties and the issues in the two actions are at least technically different. ${ }^{14} \mathrm{~A}$ more cogent criticism of the rule recognizes the differences in the degrees of proof required in civil and criminal actions, ${ }^{15}$ as well as the accompanying differences in rules of evidence ${ }^{16}$ and procedure. ${ }^{17}$ If the Coffey rule depends upon giving breadth to the protections against double jeopardy, an inconsistency appears when the complement of the rule, that a prior conviction is no bar to a later civil proceeding, is considered. ${ }^{18}$ Another attack might rest on the probable legislative intent; the problem most frequently arises under statutes which create from a single occurrence two separate causes of action, one civil and one penal. It may be argued, therefore, that the legislature, when drafting these statutes, intended that there should be no bar to a second proceeding..$^{19}$ Finally, there is a pragmatic defect in the rule: Under identical circumstances as to two separate defendants, if the Government should proceed first in the criminal court against defendant $A$ and fail, the civil remedy is not recoverable as against $A$. If, however, the Government should proceed

\footnotetext{
${ }^{14}$ See Stone v. United States, 167 U.S. 178,188 (1897), where the Court noted the dissimilarity of issues between criminal and civil trials.

In order that res judicata be applicable, there must be identity of parties. United States v. Certain Bottles of Lee's "Save the Baby," 37 F.2d I37 (D.C. Conn. 1929) (no evidence that the same persons composed a partnership at the time of both actions); United States v. One Dodge Sedan, I I3 F.2d 552 (3d Cir. 1940) (wife of the acquitted driver of "convoy" car allowed to prove inculpability of car).

${ }^{15}$ Stone v. United States, 167 U.S. 178 (1897); Murphy v. United States, 272 U.S. 630 (1926). The distinction announced by the Court is that for conviction the guilt of the accused must be proved beyond a reasonable doubt, while in a civil action liability may be predicated upon merely a preponderance of the evidence.

${ }^{16} E$.g., generally the good or bad character of either party to a civil action is inadmissible; however in a criminal action the character of a defendant may be attacked only after the defendant has put into issue his own good character. Roberson v. State, 91 Okla. Crim. 217, 218 P.2d 414 (1950).

${ }^{17}$ E.g., the privilege of a criminal defendant to refuse to testify against himself as opposed to the absence of such a privilege in a civil action. 2 FrEEMAN, JUDGMENTS $\&$ 654 (5th ed. 1925).

${ }^{18}$ See Various Items of Personal Property v. United States, 282 U.S. 577 (1931). See also note 3 supra.

${ }^{10}$ Cf. United States v. United States Gypsum Co., 51 F. Supp. 613 (D.D.C. 1943). An injunction under the Sherman Act, 26 STAT. 209 (1890), as amended, 5 U.S.C. $\S \S \mathrm{I}, 4$, was granted although the defendants had been previously acquitted in an action where the Government sought criminal actions against a combination in restraint of trade. Similarly the Internal Revenue Code makes provision for both civil and/or criminal actions based upon the same act or omission. United States ex rel. Marcus v. Hess, 317 U.S. 537 (1943). See note 5 supra.
} 
first against defendant $B$ in a civil action, it might recover judgment under the less rigorous standard of proof and yet fail in the later criminal action. Thus civil recovery might depend upon the fortuity of the character of the initial action.

Some authorities contend that much of the effect of the Coffey case has been attenuated by the later case of Helvering v. Mitchell, ${ }^{20}$ where the Supreme Court ruled that an acquittal in a prior criminal action would not bar subsequent proceedings which are civil or remedial in nature as distinguished from those which are criminal or penal. A cursory examination of these two cases could lead to the conclusion that the latter case has virtually all but overruled the former. Despite the antithetical results, however, a closer analysis reveals a common point upon which both cases may be rested, i.e., the concern of the Court to thwart government efforts to use a disguised civil action as a vehicle to impose otherwise unavailable criminal sanctions. ${ }^{21}$

In Inman v. United States, the court preferred to follow the Coffey rule, and evidently felt that the levying of a tax upon mash fit for distillation was inherently based on violation of the criminal laws, ${ }^{22}$ although the applicable section of the Internal Revenue Code has been judicially interpreted otherwise. ${ }^{23}$ Assuming the court's conclusion in the Inman case to be correct, although it may be argued that the Government was merely seeking to obtain payment for the privilege of manufacturing alcoholic spirits, ${ }^{24}$ the Mitchell case could have been used more

\footnotetext{
${ }^{20} 303$ U.S. 391 (1938) (upholding the assessment of a statutory fraud penalty upon a taxpayer who, in a previous criminal action, had been acquitted of filing a fraudulent return).

${ }^{21}$ In the Coffey case the court held that there could be no new trial of the accused after a previous acquittal, and that a subsequent trial, ostensibly civil, was fundamentally criminal when the only distinction between the two was the consequence following judgment. II 6 U.S. at 443. This conclusion may have been premised upon an old notion that a forfeiture action was inherently criminal. Various Items of Personal Property v. United States, 282 U.S. 577 (1931). It seems that the decision in the Coffey case was motivated by the same considerations which underlie the safeguard against double jeopardy. Under the Mitchell rule this consideration is retained by employing the concept of an action penal in nature as opposed to one civil in nature.

${ }_{22}{ }_{15} \mathrm{I}$ F. Supp. at 786.

${ }^{23}$ See also, United States v. United States Industrial Alcohol Co., ro3 F.2d 97 (4th Cir. 1939), where the legislative history of INT. Rev. CODE of 1954, § 5005(b), is examined. See also, Hudson v. Crenshaw, 224 F.2d 324 (4th Cir. 1955); Ferroni v. United States, 53 F.2d 1013 (7th Cir. I93I).

${ }^{24}$ See United States v. Constantine, 296 U.S. 287 (1935), where it was argued that it would be anomalous to require a tax from a licensed manufacturer and not from an illict distiller.
} 
effectively to reach the same conclusion through exploitation of the distinction between remedial and penal sanctions. ${ }^{25}$ Thus, a just result, barring successive criminal actions, could be obtained without impeding the collection of bona fide taxes and civil statutory penalties.

${ }^{25}$ Because these concepts are not rigidly defined, the court could more easily examine the actual object and the purpose of the action. Cf. United States v. La Franca, $28 z$ U.S. 568 (1931); Murray \& Sorenson v. United States, 207 F.2d I19 (1st Cir. 1953). 